\title{
NOTES
}

\section{THE ENFORCIBILITY OF TREASURY BONDS IN BANKRUPTCY AND REORGANIZATION*}

CORPORATIONS repurchase their own bonds for a variety of reasons. ${ }^{1}$ For example, bond repurchases enable a corporation to reduce interest expense as its need for borrowed capital decreases. Moreover, a corporation contemplating future borrowing can improve its credit rating by judicious repurchasing to sustain the market price of its bonds. ${ }^{2}$ However, the repurchase of bonds will entail a loss of financial flexibility unless the bonds can be reissued or pledged as security for a corporate note. Normally an indenture authorizes a limited number of bonds and secures them by a mortgage on all corporate assets, including those to be obtained in the future. ${ }^{3}$ Consequently, if reacquired bonds cannot be reissued or pledged, repurchase permanently reduces the capital obtainable through financing which is secured by a mortgage of the same priority as that authorized by the indenture. Hence, increased financial needs may ultimately necessitate the execution of an unsecured credit instrument or a mortgage junior to the indenture mortgage. Borrowing on either

*In re Third Avenue Transit Corp., 120 F. Supp. 839 (S.D.N.Y. 1954), appeal dockeled, Nos. 23141-45, 2d Cir., June 1, 1954.

1. For an excellent general discussion of corporate mortgage financing, see 1 Dewing, The Financial Policy of Corporations cc. 7-9 (5th ed. 1953). See also McClelland \& Fisher, Corporate Mortgage Bond Issues (1st ed. 1937).

2. Bond repurchase may also enable a corporation to meet its sinking fund obligations economically. Bond indentures often require the mortgagor to maintain as sinking fund as insurance for the ultimate redemption of the entire bond issue. The corporation must make annual contributions to the fund to enable the fund's trustee to buy a specificd number of bonds, or the corporation itself may be required to repurchase and cancel a percentage of the outstanding bonds. In either case management is able to defray this expense most economically by repurchasing the bonds when their market price is low and then holding them for later cancellation or sale to the fund. For a discussion of common sinking fund requirements, see 1 Dewing, op. cit. supra note 1 , at 239-50.

3. See, e.g., In $r c$ Third Avenue Transit Corp., 120 F. Supp. 839, 843 (S.D.N.Y. 1954) ; 1 DewING, op. cit. supra note 1, at 198, 209. For a discussion of bond issues without these characteristics, see note 4 infra.

4. See Berle \& Warren, Cases and Materials on the Law of Business OrganiZATION 917 (1st ed. 1948), and authorities cited therein. Of course this will not occur where the mortgage is of the "open-end" type. Under such a mortgage there is no specific upper limit to the total number of bonds which may be issued and secured by the same lien rights in the mortgaged property. However, many so-called "open-end" mortgages are restricted in that they limit additional bonds to a specific percentage of the fair value of later acquired property or improvements. Where this is the case, newly acquired property may not be sufficiently valuable to authorize issuance of the number of bonds needed for expanding financial needs. Thus there would be in practical effect an exhaustion of the mortgage similar to that of a closed mortgage. See 1 DewrNG, op. cit. supra note 1 , at $184-86$. 
type of instrument entails high interest payments. ${ }^{5}$ Moreover, stringent requirements must be met before state and federal governnent approval can be obtained for a new flotation of securities. ${ }^{b}$ Thus the corporate need for the power to reissue or pledge reacquired bonds is apparent, and most courts have granted this power whenever a company has shown its intention to retain reacquired bonds for subsequent borrowing. " However, judicial determination that repurchased bonds in the company's treasury may be "alive" for future financing has created confusion over their status when the corporation goes through bankruptcy or reorganization.

In the recent case of $I n$ re Third Avcnue Transit Corp., 8 a company's reorganization trustee asked a New York federal district court for a declaratory judgment determining the status of repurchased bonds held in the corporation's

5. This is caused by the reduced salability of unsecured debentures and bonds secured by an inferior mortgage. The investor will risk his capital in these more doubtiul issues only where a relatively high interest rate is offered. For discussion of the general attributes and investment value of second and later mortgage bonds and debentures, see 1 Dewing, op. cit. supra note 1 , at 208, 226, 251.

6. See discussion of state Blue Sky Laws, particularly the description of control over bond issues exercised by public service commissions, in 6A FLETCuER, CyCLorend Private Corporations $\$ 2656$ (perm. ed. 1950); 2 Jones, Bonds and Bo:d Secutrutes $\$ \S 640-49$ (4th ed. 1935). For an example of the statutory control exercised by state public service commissions over issues of stock, bonds, and other forms of indebtedness, see N.Y. Public Service Law § 55. Federal control over mortgage financing and the sale by corporations of securities of all types is sccurcd by the following legislative enactments: 48 SтAт. 74 (1933), 15 U.S.C. $\$ \$ 77 a-a 3$ (1952) (Sccurities Act of 1933); 53 STAт. 1149 (1939), 15 U.S.C. $\$ \S 77 a a a-b b b b$ (1952) (Trust Indenture Act of 1939); 41 STAT. 494 (1920), as amended, 49 U.S.C. $\$ 20$ a (1952) (Transportation Act). Under $\$ 20 \mathrm{a}(5)$ of the Transportation Act, a carrier must file with the Interstate Commierce Commission a certificate of notification setting forth certain facts upon the disnasitiun, sale, pledge, or repledge of securities described in a previous application. Thus, fur bund issues authorized by the Commission, even the repledge or reissuance of previously authorized securities is subject to some control.

7. American Brake Shoe \& Foundry Co. v. New York Rys., 277 Fed. 261 (S.D.N.1: 1921) ; Slupsky v. Westinghouse Electric \& MIfg. Co., 78 F.2d 13 (Sth Cir. 1935) ; Washington Loan \& Trust Co. v. Blair, 75 F.2d 671 (D.C. Cir. 1935); Virginia Securities Corp. v. Patrick Orchards, $20 \mathrm{~F} .2 \mathrm{~d} 78$ (4th Cir. 1927); Claflin v. The South Carolina R.R., 8 Fed. 118 (C.C.S.C. 1880) ; 258 Ky. 817, 81 S.W.2d 896 (1935) ; Pruyne v. Adams Furniture \& 1 ifg. Co., 92 Hun 214, 36 N.Y. Supp. 351 (Sup. Ct. 1895), af̂fd, 155 N.Y. 629, 49 N.E. 1103 (1898) ; First Security Trust Co. v. John H. Scely \& Sons Co., \&7 Utah 525, 51 P.2d 1060 (1935) ; Broomall v. North American Steel Co., 70 W. Va. 591, 74 S.E. 863 (1912). Cf. In re Fifty-Four First Mortgage Eonds, 15 S.C. 304 (1830) (reissue of matured bonds permitted). But cf. Anderson v. Pennsylvanis Hotel Co., 5 u F.2d 980 (5th Cir. 1932) (repurchased matured bonds not reissuable). For a much-cited statement of the principle, see 2 JoNEs, op. cit. supra note 6, at \$757. See also 4 Coor, Corporations 3396 n.4 (8th ed. 1923); 6A Fletcher, op. cit. sufra note 6, $\$ 2729$; 3 Thonrpson, Corporations $\$ 2401$ (3d ed. 1927). For express judicial recognition of the practical reasons for allowing reissuance, sec Barry v. Mfissouri, K. \& T. Ry., 34 Fed. 829, 833 (C.C.S.D.N.Y. 1888).

8. 120 F. Supp. 839 (S.D.N.Y. 1954). 
treasury. $^{9}$ Securities of the reorganized company were to be distributed among creditors in proportion to the value of their enforcible claims against the insolvent corporation.10 The reorganization trustee, successor to the company's title in the treasury bonds, argued that they were outstanding debts and therefore entitled to share in the mortgaged assets on a par with bonds publicly held. ${ }^{11}$ This contention was supported by the general creditors. ${ }^{12}$ They stood to benefit from a determination that the treasury bonds were outstanding and enforcible, since the bonds would then be assets in the hands of the trustee and subject to general creditors' claims. Thus, they could indirectly reach the mortgaged property securing these bonds, and would therefore have more valuable claims for purposes of reorganization. ${ }^{13}$ But, since the mortgaged

9. In re Third Avenue Transit Corp., 120 F. Supp. 839, 841 (S.D.N.Y. 1954). Under a First Refunding Mortgage dated December 20, 1911, the Third Avenue Railway Co., predecessor of the Third Avenue Transit Corp., issued a total of $\$ 21,990,500$ bonds. $\$ 1,478,000$ face amount of these bonds had been cancelled by the indenture trustec, leaving $\$ 20,512,500$ of the First Refunding Mortgage bonds uncancelled at the date of the filing of an involuntary petition for reorganization on Oct. 25,1948 . Of this $\$ 20,512,500$, the corporation had reacquired $\$ 5,681,500$-the so-called "treasury bonds" involved in the litigation. $\$ 14,831,500$ face amount of First Refunding Bonds are held by the public. Brief for Reorganization Trustee, pp. 1-3, In re Third Avenue Transit Corp., 120 F. Supp. 839 (S.D.N.Y. 1954) [hereinafter cited as Brief for Petitioner] ; Brief for Appellant to the United States Court of Appeals for the Second Circuit, pp. 2-4, In re Third Avenue Transit Corp., 2d Cir., appeal brief filed Aug. 6, 1954 [hereinafter cited as Bricf for Appellant]. The Third Avenue Transit Corp. is undergoing reorganization under Chapter $X$ of the Bankruptcy Act. 47 STAT. 1474 (1933), 11 U.S.C. § 205 (1952).

10. In re Third Avenue Transit Corp., 120 F. Supp. 839, 842 (S.D.N.Y. 1954). For a discussion of the principles governing the exchange of securities in reorganization, sce 2 Dewing, The Financial Policy of Corporations 1368-81. (5th ed. 1953); Comment, 63 Yale L.J. 812 (1954); Comment, 61 Yale L.J. 656 (1952); Comment, 51 Yale L.J. 85 (1941).

11. In re Third Avenue Transit Corp., 120 F. Supp. 839, 841, 842 (S.D.N.Y. 1954). The brief for the petitioner stated that he "owned" the treasury bonds. Brief for Petitioner, p. 1. The reply brief for the respondent pointed out that the reorganization trustee succeeded to whatever "title" the debtor itself had in the bonds and no more, and that the principal issue was whether the rights of an owner devolved on the reorganization trustee. Joint Reply Brief for the First Refunding Mortgage Representatives, pp. 1-2, In. re Third Avenue Transit Corp., supra. The reorganization trustee referred to the treasury bonds variously as "outstanding" bonds, as bonds held without cancellation for "investments," as "issued and outstanding" bonds, and as "live bonds." Brief for Petitioner, pp. $3,9,15,16,17$.

12. It $r e$ Third Avenue Transit Corp., 120 F. Supp. 839, 841 (S.D.N.Y. 1954). The holders of some $\$ 22,215,900$ of bonds outstanding under the Adjustment Income Mortgage, secured by a second lien on all corporate properties, a lien inferior to the lien of the First Refunding Mortgage, supported the position of the reorganization trustce. Since the mortgaged assets were insufficient to cover the claims of the first mortgagees, sce note 14 infra, these claims of the second mortgagees could derive no value from their security. Consequently whatever value their claims had would be attributable to thcir sharing in unsecured assets as general creditors. Joint Brief for Indenture Trustee and First Refunding Bondholders, p. 1, In $r c$ Third Avenue Transit Corp., supra [hereinafter cited as Brief for Respondent]; Brief for Appellant, pp. 3, 4.

13. In re Third Avenue Transit Corp., 120 F. Supp. 839, 842 (S.D.N.Y. 1954). Sec articles cited note 10 supra. 
assets were of insufficient value to indemnify the public bondholders, ${ }^{14}$ the indenture trustee sought to prevent any diminution of their security. He contended that treasury bonds could never be considered "outstanding obligations."'15

The court, accepting the arguments of the reorganization trustee, decreed the bonds to be enforcible claims. ${ }^{10}$ Its decision was grounded upon a finding that the corporation intended to keep the bonds uncancelled for possible future financing. ${ }^{17}$ However, the holding that the bonds were enforcible need not have made them and their security available for general creditors, since the after-acquired property clause in the public bondholders' mortgage could have been construed to cover treasury bonds. ${ }^{18}$ The court avoided this possibility by applying to the bonds the New York rule that an after-acquired property

14. See letter from Frank H. Heiss, Esq., of Kelley, Drye, Newhall \& Mraginnes, attorneys for the indenture trustee, to the Yale Law Journal, dated Dec. 3, 1954, on file in Yale Law Library.

15. In re Third Avenue Transit Corp., 120 F. Supp. 839, 842 (S.D.N.Y. 1954). In his brief the indenture trustee states: "Regardless of the intent with which they were acquired by Third Avenue, the Treasury Bonds are not entitled to share in the security ...." Brief for Respondent, p. 5. He argued that unissued bonds "are nut outstanding for any purpose," ibid, and that treasury bonds have the same status as unissued bonds. Id. at 7.

16. In re Third Avenue Transit Corp., 120 F. Supp. 839, 844, 848 (S.D.N.Y. 1954).

17. Id. at $845,846,847$. The court expressed the belief that corporations continue to treat repurchased bonds as if they were still alive in order to support a claim that they have not been cancelled. This would be important, said the court, "in the event of a subsequent desire to resell the bonds." Id. at S43. Since reacquired bonds are normally held uncancelled to provide the corporation with maximum flexibility for future capital needs, see text at notes 3-6 stpra, the discovery of this intention was almost a foregone conclusion.

There were three groups of treasury bonds involvcd in the proceedings, referred to for convenience by the name of the particular fund moneys with which they were repurchased:

a) $\$ 1,667,000$ of "Sinking Fund" bonds, so-called because the moneys used to buy them had been set aside pursuant to three orders of the New York Public Service Commission aimed at insuring the corporation's ability ultimately to retire the First Refunding Mortgage Bonds. Id. at 845 . The court found that the second and third orders prohibited any other course of action than a cancellation of the bonds. Ibid. But the court decided that the first order did not require such a conclusion, and that the intent of the debtor to hold them alive was determinative. Id. at $\$ 15,846$.

b) $\$ 2,520,500$ of "Depreciation Fund" bonds, concerning which the court said: "Here, ... the debtor's intention has full sway. The debtor's intention to keep the bonds alive was . . clear...." Id. at S46.

c) $\$ 1,494,000$ of "Amortization" bonds. The court stated: "There can be no doubt that these bonds were originally outstanding and no doubt of the debtor's intention to keep them alive." Id. at 847.

18. Once it has been determined that repurchased bonds continue as assets of the debtor corporation while held in its treasury, they may then be capturable by an afteracquired property clause which is written to cover securities. The First Refunding Mortgage contained the following clause which might be construed to cover the afteracquired treasury bonds: 
clause cannot affect a reorganization trustee's claims to personalty. ${ }^{10}$ As a consequence, roughly one-fifth of the mortgaged assets was released from the mortgage lien. ${ }^{20}$ And the court indicated that this result would be same whether the corporation were in bankruptcy or reorganization. ${ }^{21}$

The Third Aveme Transit decision was dictated by the court's adoption of the illogical rationale, ${ }^{22}$ unsupported outside its district, ${ }^{23}$ that treasury bonds

"Also any and all lines of railroad, extensions and branches, land and improvements of any description, machinery, cars and other equipment, stock, bonds, notes and other obligations and other property of any description whatsoever, which the Railway Company may acquire by the use of bonds, or the proceeds of bonds reserved under the subdivision (3) of Article Second of this indenture, or with the procecds of any property mortgaged or pledged hereunder, or otherwise acquired under the provisions of this indenture...."

See letter from Frank H. Heiss, Esq., of Kelley, Drye, Newhall \& Maginnes, attorncys for the indenture trustee, to the Yalc Law Journal, dated Dec. 3, 1954, on file in Yale Law Library.

For a general discussion of the law pertaining to after-acquired property clauses, sce Cohen \& Gerber, The After-Acquired Property Clause, 87 U. PA. L. Rev. 635 (1939); Berle \& Warken, Cases and Materials on the Law of Business Organization 910. 17 (1st ed. 1948).

19. In re Third Avenue Transit Corp., 120 F. Supp. 839, 847, 848 (S.D.N.Y. 1954). The treasury bonds, if assets at all, are personalty. Under New York law an afteracquired property clause is not effective to prevent creditors from levying on personalty acquired after the execution of the mortgage. E.g., Rochester Distilling Co. v. Rasey, 142 N.Y. 570, 37 N.E. 632 (1894); New York Security Co. v. Saratoga G. \& El. L. Co., 159 N.Y. 137, 53 N.E. 758 (1899); Diana Paper Co. v. Wheeler-Green Electric Co., 228 App. Div. 577, 240 N.Y. Supp. 108 (4th Dep't 1930); It re Niagara Lead \& Battery Co., 202 Fed. 298 (W.D.N.Y. 1913). A bankruptcy trustee has the status which a levying creditor would have under state law. 30 STAT. 565 (1898), as amended, 11 U.S.C. $\$ 110$ (c) (1952). A trustee appointed under Chapter $X$ of the Bankruptcy Act, as was the reorganization trustee in this case, is vested with the same rights and powers as at trustco in bankruptcy, including his status as levying creditor. Nash v. Onondaga Hotel Corp., 140 F.2d 209 (2d Cir. 1944) ; 52 Stat. 892 (1938), 11 U.S.C. \$ 587 (1952). For discussion of the various state rules governing after-acquired property clauses in real property mortgages and chattel mortgages, see 4 ColLIER, BANKRuptCX Iff 70.80, 70.82 (14th ed. 1942).

20. Brief for Appellant, p. 1. Though these assets were released from the nortgagces' lien, the court did state that "insofar as holders of the publicly held First Refunding Mortgage Bonds were not paid in full, they would be general creditors entitled to share in the proceeds of the mortgaged property applicable to the Treasury Bonds along with the rest of the free assets." Thus the claims of the public bondholders to a share of securities in the reorganized company would be based to some small degree on the value of the assets securing the treasury bonds. In $r c$ Third Avenute Transit Corp., $120 \mathrm{~F}$. Supp. 839, 842 (S.D.N.Y. 1954).

21. Id. at 842 .

22. The court admitted as much when it said: "As a matter of common sense, the First Refunding Bondholders' position that the Treasury Bonds cannot be enforced against the mortgaged property seems unassailable. A man cannot owe himself money; hence there is no debt represented by the Treasury Bonds. There can be no security without a debt; hence the Treasury Bonds have no interest in the security under the mortgage. 
held uncanceled for future financing must ipso facto be "alive" for enforcement. SEC and ICC decisions apparently recognize the irrelevancy of the

\footnotetext{
"In spite of the unassailable logic of the positions of the First Refunding Bondholders, however, there are business practices which afford a specious argument against it andeven more important-court decisions that, to say the least, give the First Refunding Bondholders an uphill fight." In re Third Avenue Transit Corp., 120 F. Supp. 839, 842 (S.D.N.Y. 1954).
}

23. The court felt bound by two mortgage foreclosure decisions in its own district. In American Brake Shoe \& Foundry Co. v. New York Rys., 277 Fed. 261 (S.D.N.Y. 1921), $\$ 1,000,000$ face amount of the first mortgage bonds had been repurchased by the railways company, held in its treasury for a time, and then pledged as collateral security for a loan. At the time of mortgage foreclosure, some $\$ 18,000,000$ worth of first mortgage bonds, including those pledged, were "outstanding." The unpaid balance of the laan for which the pledged bonds were collateral was $\$ 400,000$. Certain mortgagees claimed that the pledged bonds had been extinguished by their repurchase, but the court, finding a corporate intent to hold the bonds alive, denied this plea. It held that a pro rata share of the mortgaged assets must be applied to the pledged bonds with any excess over $\$ 400,000$ to return to the debtor and be available for general creditors' claims. No cases were cited to support the holding. Judge Dimock recognized that this case might ba distinguishable on the ground that pledged bonds were involved, not treasury bonds. In re Third Avenue Transit Corp., 120 F. Supp. 839, S43 (S.D.N.Y. 1954).

Westinghouse Electric \& $\mathrm{Mffg}$. Co. v. Brooklyn R.T. Co., 228 Fed. 221 (S.D.N.Y. 1923), involved $\$ 5,092,000$ face amount of bonds held in the debtor's treasury at the time of foreclosure. Of this amount, only $\$ 20,000$ had been issued and then repurchased. The court affirmed the report of a special master who had held that this $\$ 20,000$ of bonds was entitled to share in the proceeds of the foreclosure sale. No cases were cited by the court except its earlier decision in American Brake Shoe \& Foundry Co. v. New York Rys., supra.

Within its own circuit the court could have found two circuit court cases which would have given it a rationale permitting it to overrule the southern district decisions.

Judge Learned Hand had referred to treasury bonds as "not debts at all; and ... no different from bonds never issued . . .," in a cryptic opinion deciding New York Trust Co. v. Palmer, 101 F.2d 1, 4 (2d Cir. 1939). There a railway company was being liquidated and the public bondholders, having been insufficiently reimbursed by their sceurity, were seeking to enforce as large a claim as possible against the general assets. Some reacquired bonds had been pledged to the indenture trustee for the bondholders' benefit in return for a release of part of the mortgaged property. The bondholders sought to have these pledged bonds enforced against general assets along with their claims for the balances owed to them on their own bonds. The court rested its decision mainly on the ground that to allow the enforcement of the pledged bonds would be to sanction an unlawful multiplication of claims for a single debt-the balance owed the public bondholders. This position is supported by Hitner v. Diamond State Steel Co., 176 Fed. 384 (C.C.D. Del. 1910). However, the rationale that reacquired bonds are "not debts at all" seems to have provided an alternative basis for the court's decision. New York Trust Co. v. Palmer, stipra at 4.

In an earlier mortgage foreclosure case, New York Security \& Trust Co. v. Equitable Mortgage Co., 77 Fed. 64 (C.C.S.D.N.Y. 1896), the plaintiff sought a distributive share of foreclosure proceeds on the basis of bond coupons which had been assigned to him by the debtor. These coupons had been previously redeemed by the debtor from a pledgee. The court denied the claim. It found that the plaintiff had acquired the bonds by assignment rather than issuance. To ascertain the rights of the assignee, the court then considered whether the debtor-assignor could enforce these coupons, and reached the con- 
intent test. ${ }^{24}$ Corporate intention to hold bonds for subsequent borrowing is germane only to the specific problem of whether repurchase precludes reissuance or pledge. It has no reasonable relation to the wholly different problem of whether treasury bonds should be enforced in bankruptcy or reorganization so as to favor one group of creditors over another.

When considering treasury bonds in other contexts where the question is not reissuance or pledge, courts consistently reject as a meaningless guide the corporation's intent to retain these bonds for later financing. ${ }^{25}$ For example, they have ignored corporate intent to reissue or pledge when defining the status of reacquired bonds in relation to indenture requirements for sinking fund contributions. Indentures frequently stipulate that the issuing corpora-

clusion that it could not. Although the court could have restricted the justification for its holding to the simple proposition that unissued coupons are not enforcible, it adopted the following broad language of the special master: "[I]t cannot . . . be successfully maintained that a mortgage debtor, having become possessed of bonds or coupons secured by its mortgage, can enforce them against the proceedls of the sale of the mortgaged property, where such proceeds are insufficient to pay in full the other outstanding bonds and coupons secured thereby." Id. at 66.

For additional authority contrary to the position taken by the district court, sce Claflin v. The South Carolina R.R., 8 Fed. 118, 126 (C.C.S.C. 1880) (dictum by C. J. Waitc) ; 4 CoOK, Corporattons 3396 n.4 (8th ed. 1923) ; 3 Jones, Bonds and Bond Securitues $\$ 1431$ (4th ed. 1935); Ballantine, The Curious Fiction of Treasury Shares, 34 Calif. L. Rev. 536, 542 (1946). But see Mississippi Valley Trust Co. v. Washington Northern R.R., 212 Fed. 776 (W.D. Wash. 1914), aff'd sub nom. Crawford v. Washington Northern R.R., 233 Fed. 961 (9th Cir.), cert. denied, 242 U.S. 629 (1916) (dictum) (enforccment of reissued bonds allowed but subordinated to other bonds of same issue).

24. In approving reorganization plans under Chapter $\mathrm{X}$ of the Bankruptcy Act, 52 STAT. 888 (1938), 11 U.S.C. $\$ 501-676$ (1952), and section 77 of the Bankruptcy Act, 47 STAT. 1474 (1933), 11 U.S.C. \& 205 (1952), these administrative agencies have, with one exception, treated treasury bonds as nullities to be entirely omitted from participation in the reorganized company. E.g., Rocky MIt. Fuel Co., 20 S.E.C. 24, 36 (1945); Associated Gas \& Electric Co., 15 S.E.C. 743, 761 (1944); In re Chicago, M. St. P. \& P. Ry., 254 I.C.C. 707, 708 n.5, 739 (1943). The Seventh Circuit accepted this last case's treatment of treasury bonds in In re Chicago, M. St. P. \& P. Ry., 124 F.2d 754, 760 (7th Cir. 1942), modified, 318 U.S. 523, 530 (1943). For court decisions in agrcement with the I.C.C. practice, see St. Louis Southwestern Ry. v. Henwood, 157 F.2d 337, 398, 399 (8th Cir. 1946) ; In re Wisconsin Cent. Ry., 63 F. Supp. 151 (D.C.D. Minn. 1945). But cf. In re Prudence Co., 98 F.2d 729 (2d Cir. 1938) (treasury bonds were recognized but regarded as having a lien inferior to publicly held bonds of the same issue).

25. Corporate intent to utilize reacquired matured bonds for raising capital has not been effective to prevent the extinction of the debt upon repurchase. Once the lebt was extinguished, the bond certificate was deemed cancelled and nonreissuable. Pellam Hail Co. v. A.B. \& M. Liquidation Corp., 112 F.2d 498 (1st Cir.), cert. denied, 311. U.S. 704 (1940); In re MIcDermott, 115 F.2d 582 (7th Cir. 1940); Anderson v. Pennsylvanin Hotel Co., 56 F.2d 980, 982 (5th Cir. 1932) (dictum); In re Burton, 29 Fed. 637 (W.D. Va. 1886); Cussen v. Brandt \& Dunlop, 97 Va. 1, 32 S.E. 791 (1899). Contra, In $+c$ Fifty-Four First Mortgage Bonds, 15 S.C. 304 (1880). There is much reason behind this rule, since the debtor could conceal its inability to pay the bonds on maturity by the device of pledging these bonds to a lending institution in return for a loan of the money necessary to redeem these same bonds. See Pelham Hall Co. v. A.B. \& M. Liquidation Corp., supra; Anderson v. Pennsylvania Hotel Co., supra. 
tion make periodic contributions to a sinking fund. ${ }^{20}$ This reserve acts as insurance for the ultimate redemption of the entire bond issue. ${ }^{27}$ The contributions are often measured by taking either a fixed percentage of the principal of "issued and outstanding bonds" or a stated sum for each of these bonds."3 In determining whether treasury bonds are "issued and outstanding," courts have construed the indenture in order to ascertain the reasonable expectations of both bondholders and company. ${ }^{29}$ Thus, the corporate intent to reissue, manifested when the bonds were repurchased, has been properly disregarded as irrelevant.

Furthermore, courts have accepted the argument of the Internal Revenue Service that corporate intent should not be considered in deciding when to tax gains from the repurchase of bonds below par. ${ }^{30}$ The Comnissioner, with judicial approval, has correctly refused to view treasury bonds as subsisting debts and has taxed the gain in the year of repurchase. ${ }^{31}$ To hold that no gain has been realized because the corporation as issuer still owes itself as holder the face amount of the bonds ${ }^{32}$ would not merely be unrealistic, but would permit a company to choose the year for taxation of gains actunlly received at repurchase. ${ }^{33}$

The adoption of the corporate intention test in Third Avemue Transit resulted in a holding without policy justification. Admittedly, no investor in mortgage bonds should generally expect to receive a proportional share of the liquidated security larger than the fractional relation his holdings bear to all

26. See 1 Dewing, The Finaxcial Policy of Corforations 239-40 (5th ed. 1953).

27. Id. at 239. See also 2 Jones, Boxns And Bond Securitres \$ 619 (4th ed. 1935).

28. 1 Dewing, op. cit. supra note 26, at 241-246. For a typical sinking fund provision, see Bankers Trust Co. v. Denver Tramway Co., 192 App. Div. 794, 795, 183 N.Y. Supp. 326, 327 (1st Dep't 1920).

29. Bankers Trust Co. v. Denver Tramway Co., 233 N.Y. 604, 135 N.E. 936, modifying 192 App. Div. 794, 183 N.Y. Supp. 326 (1st Dep't 1920) (not issued and outstanding); Cincinnati Gas \& Electric Co. v. New York T. Co., 215 App. Div. 122, 213 N.Y. Supp. 314 (1st Dep't 1926) (issued and outstanding); New York Trust Co. v. Portland Ry., 197 App. Div. 422, 189 N.Y. Supp. 346 (1st Dep't 1921) (same); Columbia Gas \& Electric Co. v. Knickerbocker Trust Co., 152 App. Div. 5, 136 N.Y. Supp. 840 (1st Dep't 1912) (same).

30. E.g., Tennessee Consol. Coal Co. v. Commissioner, 145 F.2d 631 (6th Cir. 1944); Garland Coal \& Mining Co. v. Helvering, 75 F.2d 663, (D.C. Cir. 1935); American Brake Shoe \& Foundry Co. v. Interborough Rapid Transit Co., 19 F. Supp. 234 (S.D.N.X. 1936) ; Houston Natural Gas Corp., 9 T.C. 570 (1947). These cases prevented corporations from using postponement of retirement to choose the year for tasation. For a history of the treatment of this problem by the courts and the Internal Revenue Service, see Commissioner v. Pittsburgh \& W.V. Ry. 172 F.2d 1010 (3rd Cir. 1949), especially at p. $1015 \mathrm{n} .13$.

31. See cases cited note 30 supra.

32. This was the company's contention in Tennessee Consol. Coal Co. v. Commissioner, 145 F.2d 631 (6th Cir. 1944). The debtor claimed that the reacquired bonds were held as investments, and simultaneously carried them as liabilities on the company's books. See also, e.g., Montana, W. \& S.R.R. v. Commissioner, 77 F.2d 1007 (3d Cir. 1935).

33. See note 30 supra. 
bonds authorized by the indenture, whether issued or not. ${ }^{34}$ However, where mortgaged assets are insufficient to reimburse the bondholders in full, they have a right to anticipate that their prior lien will prevent junior claimants from sharing in the security. ${ }^{35}$ Moreover, the reasonable expectations of general creditors, judged at the time they extend credit, undoubtedly do not include the subjection of mortgaged assets to their claims before the mortgagees are fully repaid. ${ }^{36}$ At best, general creditors can expect that repurchase will enhance their chances for participation in mortgaged assets by reducing the outstanding claims of senior mortgagees. Thus, Third Avemue Transit sanctioned a windfall to general creditors and thwarted the reasonable expections of public bondholders.

The inequity of the decision is further highlighted by its unjustifiable frustration of the indenture's after-acquired property clause. It is true that under New York law the recording of a mortgage containing such a clause will not prevent a levying creditor from avoiding a bondholder's lien on after-acquired personalty. ${ }^{37}$ Therefore the Third Avenue Transit holding that the mortga-

34. Claflin v. The South Carolina R.R., 8 Fed. 118, 124 (C.C.S.C. 1880). The investor in bonds is given constructive notice of the number of bonds authorized under the mortgage indenture. He must anticipate that the corporation may issue all the authorizcd bonds, thereby reducing the security behind each bond to the allowable minimum. See Note, 47 Y ALE L.J. 480, 481 (1938), for a statement of this proposition with respect to holders of mortgage participation certificates.

35. E.g., Consolidated Rock Products Co. v. DuBois, 312 U.S. 510 (1941); Case v. Los Angeles Lumber Products Co., 308 U.S. 106 (1939); Northern Pacific Ry. v. Boyd, 228 U.S. 482 (1913). These decisions have formulated the "absolute priority" rule which governs the distribution of securities of the reorganized corporation among creditors and stockholders of the old company. The rule denies participation by junior claimants when "full" compensation has not been received by seniors. It will be applied in bankruptcy reorganizations under section 77 of the Bankruptcy Act, 47 STAT. 1471 (1933), 11 U.S.C. $\S 205$ (1952), see Ecker v. Western Pacific R.R., 318 U.S. 448 (1943); and under Chapter $X$ of the Bankruptcy Act, 52 Stat. 883 (1938), 11 U.S.C. $\$ \$ 01-676$ (1952) (formerly section 77B of the Bankruptcy Act, 48 Stat. 912 (1934)), see Case v. Los Angeles Lumber Products Co., sttpra.

In mortgage foreclosure proceedings the lien holders must expect to be paid in order of their priority, with juniors sharing only after seniors have been fully reimbursed. Walsh, Mortanges § 79 (1st ed. 1934).

36. The widely accepted "absolute priority" rule as well as the distribution normally made in mortgage foreclosure proceedings probably determines the expectations of gencral creditors. See note 35 supra. They receive higher interest on the money they lend for the specific reason that they are willing to sacrifice security for the prospect of an increased return.

37. See notes 18 and 19 sitpra. This rule is severely criticized in an article by Harlan F. Stone, The "Equitable" Mortgage in New York, 20 CoL. L. Rev. 519 (1920). See also Walsh, MorTgages 57-63 (1st ed. 1934), where the New York rule is described not only as a minority position, but also as out of harmony with a line of cases in New York itself extending from Kribbs v. Alford, 120 N.Y. 519, 24 N.E. 811 (1890). The Kribbs case holds that recordation of a mortgage containing an after-acquired property clause protects the mortgagees' lien on after-acquired property by giving constructive notice to a subsequent purchaser. That the position of the levying creditor who advanced money without reliance on chattels to be acquired in the future should be more favorable 
gees' after-acquired property clause did not negate the right of the reorganization trustee to the bonds seems superficially correct, since bonds are personalty and a reorganization trustee has all the rights of a levying creditor.88 However, the effects of the holding are contrary to the spirit of the New York rule. The security for the bonds included not only after-acquired personalty, but also assets which a reorganization trustee cannot reach under the New York rule-personalty and realty acquired before the execution of the mortgage and after-acquired realty. ${ }^{39}$ But in Third Avinue Transit, the trustee did reach such property by using the treasury bonds as a conduit for withdrawing assets from under the mortgage lien, a nullification of contract which the bondholders could not have reasonably expected..$^{20}$ Since the security coverage of most inden-

than that of the innocent purchaser of those chattels is called a "curious legal incongruity" by Stone Stone, supra at 52S. Stone's article concludes by recommending that the mortgage lien on after-acquired property, including chattels, be upheld where the mortgage having the after-acquired property clause is properly recorded. Id. at 535. Cohen and Gerber strongly advocate the same solution. Cohen \& Gerber, The After-Acquircd Propcrty' Clause, 87 U. PA. L. Rev. 635 (1939). For further citation of cases supporting the majority and minority positions, see WALSH, supra at $60 \mathrm{n.21} ; 4$ CoLLIER, BAviEnUPTCY $\S 70.82$ (14th ed. 1942).

38. See note 19 supra.

39. For a statement of the security coverage of the mortgage, see letter from Franls H. Heiss, Esq., of Kelley, Drye, Newhail \& Mfaginnes, attorneys for the indenture trustee, to the Yale Law Journal, dated Dec. 3, 1954, on file in Yale Law Library. The First Refunding Mortgage was executed on Feb. 8, 1912 immediately after a reorganization of the Third Avenue Railroad Co., predecessor of both the Third Avenue Railway Co. and the present debtor, Third Avenue Transit Corp. Brief for Appellant, rp. 2-3. At the date of the mortgage execution the mortgagor was possessed of all the assets of the old railway company. Ibid. Therefore, it is safe to assume that a part of the mortgaged property now held by the indenture trustee is not after-acquired property.

The known cases in which the New York rule has been applied have without exception concerned the mortgage of after-acquired personalty and have stated the rule as being restricted to personalty. See cases cited note 19 supra. In their article, Cohen and Gerher state: "An attempt to mortgage land to be acquired in the future should always be upheld... The great weight of authority favors this view." Cohen \& Gerber, The AficrAcquircd Property Clazse, S7 U. PA. L. Rer. 635, 654 (1939). See also 5 Tiffarir, REAL Property $\$ 1385$ (3d ed. 1939), for statement and cases supporting the mortgage of after-acquired real property.

Of course, where no after-acquired property clause is included in the mortgage indenture, both realty and personalty acquired after the mortgage execution could be obtained by the reorganization trustee.

40. Since the New York after-acquired personalty rule is in disrepute, see note 37 supra, the court was ill-advised to extend its operation. A closer look at the substance of the claim advanced in behalf of the treasury bonds would have revealed that in reality the creditors were not lerying upon the bonds, but upon the security of the bonds, made up in part of assets exempt from the rule as it stood.

Despite the New York after-acquired property rule, an exception is made in the case of public utility corporations, which allows such clauses to be valid. Ithaea Trust $C o$. v. Ithaca Traction Corp., 248 N.Y. 332, 162 N.E. 93 (1928); American Brale Shoe \& Foundry Co. v. New York Rys., 277 Fed. 261 (S.D.N.Y. 1921). Howevcr, Judge Dimoels found that the exception did not cover the treasury bonds for it was limited to "property" necessary and appropriate for the operation of [the public utility's] franchises." In re 
tures is similar to that of the mortgage involved in Third Avenue Transit, ${ }^{11}$ application of the rule of this case will generally result in the circumvention of afteracquired property clauses. ${ }^{42}$

The Bankruptcy Act clearly does not contemplate treasury bonds as being enforcible claims. Sections 556 and 558 disqualify a creditor of a company from being its reorganization or bankruptcy trustee. ${ }^{43}$ Yet the trustee is a bondholder creditor under the Third Avemue Transit rule, since he succeeds to the corporation's title to the enforcible bonds. ${ }^{44}$ Moreover, the Act provides

Third Avenue Transit Corp., 120 F. Supp. 839, 848 (S.D.N.Y. 1954), citing Pintsch Compressing Co. v. Buffalo Gas Co., 280 Fed. 830, 836 (2d Cir. 1922). Had the court chosen to look behind the bonds to their security, the after-acquired property clause would clearly have been valid under this exception.

In accepting the position of the reorganization trustee regarding the New York rule, the court left unanswered an alternative contention. The second mortgagecs claimed that the after-acquired property clause in the First Refunding Mortgage was ineffective to subject the treasury bonds to its lien because bonds issued under a mortgage cannot be subject to its lien. See $I n$ re Third Avenue Transit Corp., supra at 847. This contention would probably not have held up under the court's scrutiny. It is directly opposed to Crawford v. Washington Northern R.R., 233 Fed. 961 (9th Cir. 1916). In that case a railroad company had contracted with a second mortgagee to reissue to him reacquired bonds of a prior mortgage. The second mortgagee was held to have no present right to the reacquired bonds because they came under the after-acquired property clause of the first mortgage- the mortgage under which the bonds had been issued.

41. Generally, where any mortgage is executed after the corporation has been in existence for a time, the mortgaged assets will include some property owned prior to the date of the mortgage.

Berle and Warren state: "Most corporate mortgages do not attempt to convey specific items of real or personal property owned by the mortgagor. Rather do they mortgage all of the assets of the corporation then or thereafter owned, whether real or personal, tangible or intangible." Berle \& Warren, Cases and Materials on the Law of Bus1jess Organization 908 (1st ed. 1948). See also Note, 49 Harv. L. Rev. 947, 948 (1936).

42. The inequity of the decision is further emphasized by the fact that a large part of the actual moneys exchanged for the treasury bonds had been segregated by the transit corporation for maintenance, replacement, and renewal of the mortgage security. Assuming the fund quotas were set up in accordance with depreciation needs, the allocation of these moneys to the repurchase of bonds may have resulted in a reduction of the market value of the mortgage security. In this event, the public bondholder might claim that their use to reacquire bonds constituted a breach of the indenture maintenance covenant. Sce note 17 sitpra.

A further anomalous consequence was that the sinking fund, created under Public Service Commission orders to protect the public bondholders, ultimately resulted in the diversion of their security, since the fund monies were partially invested in the treasury bonds. See note 17 supra.

43. The Bankruptcy Act provides: "Any trustee appointed under this chapter shall be disinterested . . ." 52 Stat. 888 (1938), 11 U.S.C. \& 556 (1952).

"A person shall not be deemed disinterested, for the purposes of sections 556 and 557 of this title, if

(1) he is a creditor ... of the debtor ..." 52 STAT. 898 (1938), 11 U.S.C. $\$ 558$ (1952).

44. The title to whatever assets the corporation has is taken over by the reorganization trustee pending acceptance of the reorganization plan. 52 STAT. 892 (1938), 11 U.S.C. $\S 586$ (1952). If the treasury bonds are assets, then the reorganization trustee would 
that "two-thirds in amount of the claims filed and allowed" must assent prior to court acceptance of any reorganization plan. ${ }^{45}$ Under this provision, only real parties in interest are allowed to exercise control over reorganization. ${ }^{10}$ But under the Third Avenue Transit rule, the reorganization trustee is holder of an enforcible and hence presumably provable claim; thus, a literal interpretation of the Act would include him among those given control over the distribution of rights in the reorganized company. ${ }^{47}$ Perhaps it is the difficulty of harmonizing the enforcibility of treasury bonds with the evident meaning of the Bankruptcy Act which has led the ICC and SEC to treat these bonds as nullities in reorganization. 48

The one apparently substantial argument in favor of Third Avenuc Transit is that holding treasury bonds nonenforcible would jeopardize their reissuability. Reissuability has been justified by the rationale that after a bond is issued it has all the attributes of an outstanding bond until formal cancellation. ${ }^{49}$ Hence a repurchased but uncancelled bond is "alive" and may be resold or pledged. Since nonenforcibility would deprive treasury bonds of an attribute of subsisting bonds, strict application of the above rationale would deny reissuability. However, decisions focusing on issues other than reissuability indicate that a bond need not be "alive" for all purposes to be "alive" for one. For example. courts have held that while certain reacquired bonds retained in a sinking fund could not be reissued, they were "alive" for purposes of measuring sinking fund contributions." Furthermore, while courts

have title to them and hence beconie a creditor. See section 106(4) of the Bankruptcy Act which defines a creditor as "the holder of any claim." 52 Stat. $8 \$ 3$ (193\$), 11 U.S.C. $\$ 505(4)$ (1952).

45. 52 STAT. $\$ 92$ (1938), 11 U.S.C. $\$ 579$ (1952).

46. Only those creditors and stochhoiders "affected" by the plan are to be given control over it. 52 STAT. 884 , $\$ 92$ (1938), 11 U.S.C. \$\$ 507, 579 (1952).

47. Perhaps the reorganization trustce would be denied the right to rote on the strength of section 203 of the Eankruptcy Act. 52 STat. $\$ 94$ (193S), 11 U.S.C. \$ 603 (1952). This section requires that all votes on acceptance of the plan not made in good faith be disqualified. Considering his position, the reorganization trustee might be unable to meet this requirement. For another possible ground upon which the trustee might ba disqualified from voting, see note 46 supra. For a complete discussion of the requirements of şection 179 of the Bankruptcy Act concerning acceptance of the reorganization plan, and the citation of pertinent articles and cases, see 6 CollIER, BANRruptcy I7.35 (14th ed. 1942).

48. See note 28 supra.

49. See Westinghouse Electric \& Mfg. Co. v. Brooklyn R.T. Co., 28S Fed. 221, 236 (S.D.N.Y. 1923); American Brake Shoe \& Foundry Co. v. Nev York Rys., 277 Fed. 261, 282 (S.D.N.Y. 1921). Contra, New York Trust Co. v. Palmer, 101 F.2d 1 (2d Cir. 1939). Though part of the reacquired bonds could still be raissued under the terms of the indenture, this did not deter Judge Learned Hand from referring to them as "not debts at all." Id. at 4.

50. New York Trust Co. v. Portland Ry. 197 App. Div. 422, 189 N.Y. Supp. 346 (1st Dep't 1921) ; Columbia Gas \& Electric Co. v. Kunickerbocker Trust Co., 152 App. Div. 5, 136 N.Y. Supp. 840 (1st Dep't 1912). These cases also held that the bonds were "alive" to the extent that interest on them had to be paid to the sinking fund.

On sinking fund bonds and the mortgagor's contribution computation, see text at nute 29 supra. See also 2 Jones, Bonds and BoNd Securities $\$ 758$ (4th ed. 1935). 
have consistently permitted treasury bonds to be reissued, ${ }^{51}$ such bonds have concurrently been held cancelled for income tax computations ${ }^{62}$ and, in at least one case, for sinking fund contributions..$^{53}$

Two theories could be used to reject enforcibility without denying reissuability. First, the lien rights of reacquired bonds can be viewed as suspended. For where there is no debt, lien rights are justifiably withdrawn. ${ }^{.4}$ Upon reissuance and a recreation of the debt, the mortgage lien reattaches. ${ }^{\text {t5 }}$ Second, repurchase can be regarded as simply returning the bond to the same position as that occupied by those which are authorized but as yet unissued. ${ }^{\text {s0 }}$ Such bonds are not considered existing debts until issued. ${ }^{57}$ Neither rationale precludes reissuance of the treasury bonds. ${ }^{58}$ Yet both deny them the status of enforcible debts. ${ }^{59}$

51. See note 7 supra.

52. See text at notes 30-33 supra. For a treatment of some of the tax problems concerning treasury stock, see Moore, Are Dividends of Treasury Stock Considered to Bc Taxable Inconte?, 97 J. Accountancy 179 (1954).

53. Bankers Trust Co. v. Denver Tramway Co., 233 N.Y. 604, 135 N.E. 936 (1922). For the relation of these bonds to sinking fund computations, see text at note 28 supra. See also Winkelman v. General Motors Corp., 44 F. Supp. 960, 995 (S.D.N.Y. 1942), where the court followed the Bankers Trust $C o$. decision and held that reissuable treasury stock was not "issued and outstanding" for purposes of the company's bonus plan requircments.

54. The court in Third Avenue Transit admits the "common sense" of this position. See note 22 stipra. Although the bonds may be "alive" for certain corporate purposes including reissue, it is difficult to maintain the contention that the debt itsclf actually continues. See New York Trust Co. v. Palmer, 101 F.2d 1, 4 (2d Cir. 1939); Claflin v. The South Carolina R.R., 8 Fed. 118, 124 (C.C.S.C. 1888) (dictum); RestuteMent, Contracts $\$ 432(1)$ (1932).

55. Claflin v. The South Carolina R.R., 8 Fed. 118, 126 (C.C.S.C. 1888) (dictum). This was a case where holders of second mortgage bonds disputed the first mortgage licn of holders of first mortgage bonds issued after the execution of the second mortgage. The court held that the second mortgagees had no claim to priority over any holders of first mortgage bonds. Although no reissued bonds were involved, Chief Justice Waite's opinion includes them within the scope of the principle applied by the court. He stated: "The question is thus distinctly presented whether bonds then in the hands of the company, or which afterwards got there, could be issued or reissued so as to carry with them a lien under the first mortgage as against the second." Id. at 124. "Here the bonds : . . were intended as articles of commerce, to be bought and sold . . . passed from hand to hand .... [W] Wen in the hands of the company their lien under the mortgage was suspended; but the moment they were out in the ustal course of business, it again took: effect as of the time the mortgage was given. Any other rule than this would materially impair the market value of this class of instruments, and tend to defeat the very object of their execution." Id. at 126.

56. See Ballantine, The Curious Fiction of Treastury Shares, 34 CALIF. L. REv. 536, 542 (1946); New York. Trust Co. v. Palmer, 101 F.2d 1, 4 (2d Cir. 1939).

57. E.g., Zimmermann v. Timmermann, 193 N.Y. 486, 86 N.E. 540 (1908); Equitable Trust Co. v. Great Shoshone \& Twin Falls Water Power Co., 228 Fed. 516 (D. Idaho 1915), aff'd, 245 Fed. 697 (9th Cir. 1917), cert. denied, 247 U.S. 513 (1918).

58. See notes 53 and 54 supra.

59. Bonds which have been autherticated but never issued by the corporation are not considered enforcible claims in liquidations. E.g., Westinghouse Electric \& MIfg. Co. v. 
The application of the Third Avenue Transit rule will allow a corporation, by holding its repurchased bonds, to effect in bankruptcy or reorganization the shifting of mortgaged assets from senior to junior creditors. This possibility leaves a fog of uncertainty for investors. Since, in this area, equity does not conflict with certainty, the court should have denied enforcibility by adopting the common sense position that a corporation cannot become its own creditor by holding treasury bonds. ${ }^{60}$

Brooklyn R.T. Co., 288 Fed. 221, 236 (S.D.N.Y. 1923) ; Trust Co. v. United Boxboard Co., 213 N.Y. 334, 107 N.E. 574 (1915), reversing 162 App. Div. 855, 148 N.Y. Supp. 100 (1st Dep't 1914).

60. See note 22 supra. For a case holding that a corporation cannot become its own stockholder by retaining repurchased stock in its treasury, see Borg v. International Silver Co., 11 F.2d 147, 150 (2d Cir. 1925). Two authorities on corporations take a very narrow view of the rights of the corporation as holder of its own stock, a problem similar to the definition of the status of treasury bonds. They would not view the treasury shares as assets, but only as providing an opportunity to acquire new assets if anyone wishes to buy the stocli. Ballantine, Corporatrons $\$ 260$ (rev. ed. 1946); Hills, Federal Taxation z's. Corporations Law, 12 WIs. L. REv. 280, 299 (1937). 